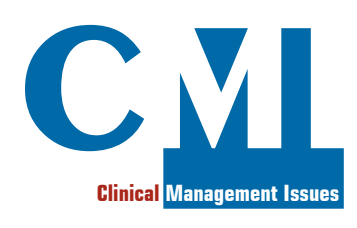

\title{
Familial Gullo's Syndrome: A Clinical Case Report
}

\begin{abstract}
This case report describes a male patient born in 1953 presenting an occasional increase in serum amylase and lipase forty years ago. The monitoring of enzymes was accompanied by radiological investigations, which did not reveal pancreatic pathology. In his family, including 10 siblings, half were carriers of this isolated anomaly; multiple cysts in pancreas, kidneys, and liver were present in some family members, in addition to a pancreatic neoplasia in a sister who did not carry the enzymatic abnormality. Ourpatient developed colon adenocarcinoma at the age of 67. Here we examine the characteristics of non-pathological chronic pancreatic hyperenzymemia defined as such by the main Italian pioneer Professor Gullo.
\end{abstract}

Keywords: Hyperamylasemia; Hyperlipasemia; Familial Pancreatic Hyperenzimemia; Gullo's Syndrome; Magnetic Resonance Cholangiopancreatography Imaging CMI 2021; 15(1): 15-24

http://dx.doi.org/10.7175/cmi.v15i1.1493

\section{INTRODUCTION}

Chronic asymptomatic pancreatic hyperenzymemia (CAPH) is a persistent abnormal increase in the serum concentrations of pancreatic enzymes without pancreatic symptoms and imaging findings of pancreatic diseases. The elevation of serum enzymes is fluctuating, with frequent and temporary findings of levels within the normal range. In 1996, Professor Lucio Gullo for the first time used the expression chronic non pathological hyperamylasemia (CNPH) of pancreatic origin and named it "Gullo's syndrome" [1,2]. CAPH has been considered a benign condition [3] that can occur sporadically or in familial forms.

\section{CASE DESCRIPTION}

In a Caucasian subject born in 1953, an increase in amylase and lipase was found during a routine blood test check carried out in 1980. The maximum values achieved were:

- for total amylases $228 \mathrm{U} / \mathrm{L}$ (normal values [nv] 10-120 U/ L);

- for pancreatic amylase $151 \mathrm{U} / \mathrm{L}$ (nv <53 $\mathrm{U} / \mathrm{L}$ );

- for lipase $766 \mathrm{U} / \mathrm{L}$ (nv <67 U/L).

\section{Why Do we Describe This Case}

The finding of isolated hyperamylasemia and/or hyperlipasemia not associated with abdominal symptoms involves a series of investigations aimed at ruling out or confirming a pancreatic pathology. The periodic oscillations of these enzymes, with intermittent return to normal values, can configure a benign chronic pancreatic hyperenzymemia, especially if associated with the finding of familiarity
Former Department of Internal Medicine, Ospedali Riuniti

Padova Sud "Madre Teresa di Calcutta", Monselice (PD), Italy 2 Former Department of Laboratory Medicine, Ospedali Riuniti Padova Sud "Madre Teresa di Calcutta", Monselice (PD), Italy
Corresponding author Mauro Turrin

m.turrin@libero.it Received: 12 January 2021 Accepted: 12 February 2021 Published: 30 March 2021 
Box 1. Drugs associated with pancreatic hyperenzimemia (modified from [6])

- Paracetamol

- Steroids

- Azathioprine

- Ephedrine

- Ritodrine

- Chemotherapy
- Roxithromycin

- Cyclosporine

- Clozapine

- Pentamidine

- Didanosine

Box 2. Drugs involved in the onset of acute pancreatitis (modified from [7])

- Didanosine

- Azathioprine/6-mercaptopurine

- Pentamidine

- Stibogluconate

- Tetracyclines: doxycycline, tigecycline

- Amoxicillin/clavulanic acid

- Metronidazole

- Methimazole

- Antihypertensives: furosemide, thiazide, $\alpha$-methyldopa

- Angiotensin-converting enzyme (ACE)-inhibitors: captopril, benazepril, enalapril, lisinopril, ramipril, quinapril

- Angiotensin receptor blockers: irbesartan, valsartan, and losartan

- Amiodarone

- Sulfasalazine

- 5-Aminosalicylic acid (mesalazine)
- Statins: simvastatin, pravastatin, rosuvastatin

- Dipeptidyl peptidase-4 inhibitors: sitagliptin, saxagliptin, alogliptin, and vildagliptin

- Glucagon-like-peptide-1 receptors agonists: albiglutide, exenatide, and liraglutide

- Sodium-glucose cotransporter 2 inhibitors: canagliflozin

- L-asparaginase

- Valproic acid

- Sulindac

- Salicylates

- Calcium

- Estrogen

- Trenbolone (anabolic steroid)

- Tamoxifen

- Antipsychotics: olanzapine, clozapine, quetiapine, and mirtazapine

- Paracetamol

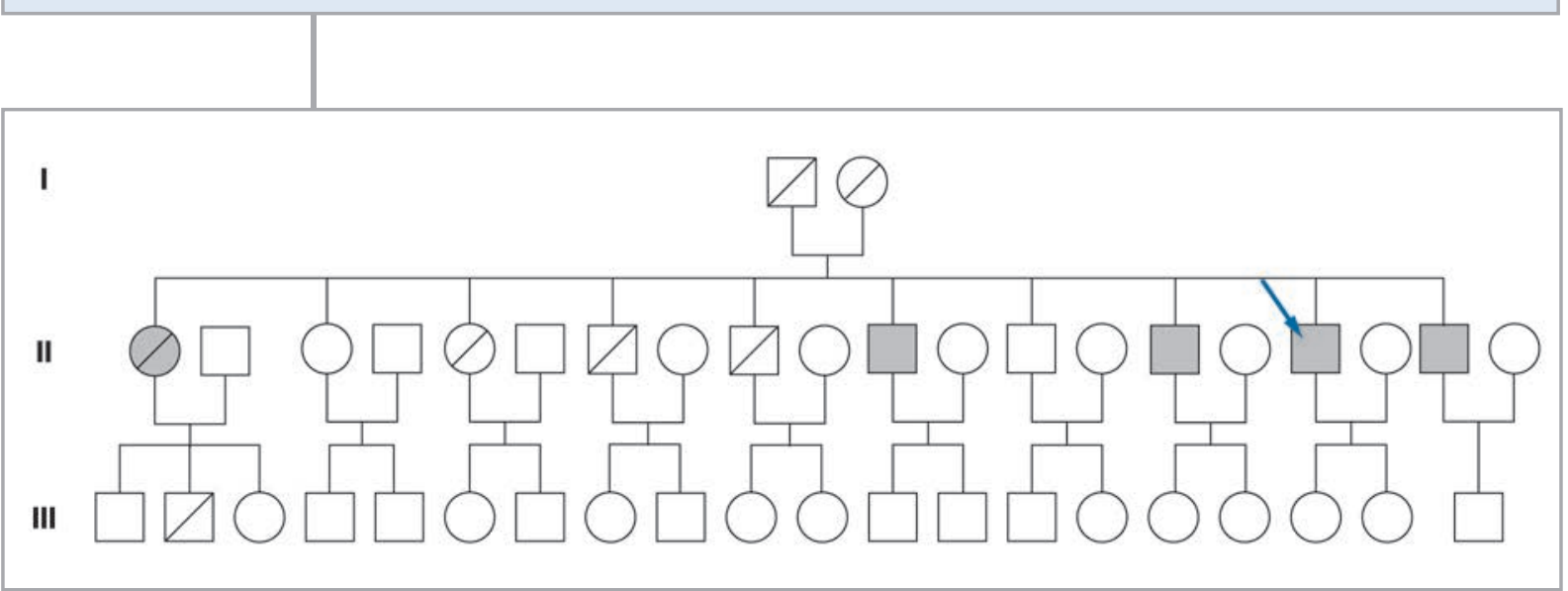

Figure 1. Genealogical tree study.

I, II, III = first, second, and third generation
These findings were never associated with abdominal pains or acute back pain. During the 40-year observation period, the increased values alternated with normal values: no pancreatic disease has been recorded so far. A first ultrasound of the complete abdomen, performed 8 years after the first finding of hyperenzymemia, showed: moderate hepatic steatosis, a small incision at the right kidney, a prostate with adenoma aspect in the central site. The patient was affected by: sleep apnea syndrome, esophageal hiatus hernia, chronic gastritis, diffuse colon diverticulosis, hyperplastic descending colon polyp, arterial hypertension, nasal obstruction, coxarthrosis (arthroplasty), chronic obstructive pulmonary disease, type 2 diabetes mellitus (in diet therapy only), thyroid node, fusiform aneurysm on the right iliac artery, and prostatic hypertrophy. A new diagnosis of renal insufficiency, viral hepatitis, Sjögren syndrome [4], celiac disease, and inflammatory bowel diseas [5] was not made. Alcohol intake was occasional and moderate. 


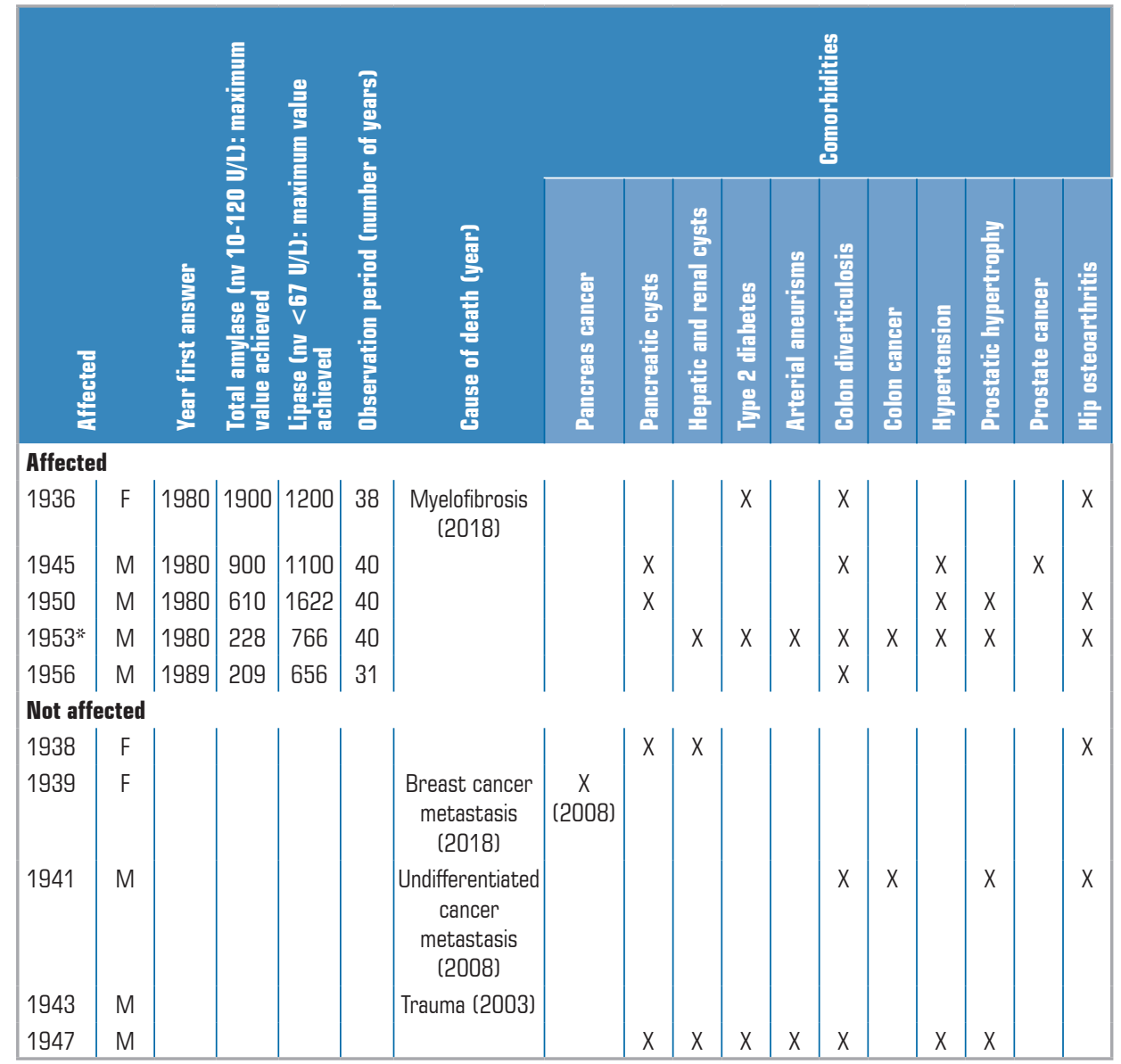

Table I. Clinical

features of the patient in analysis (*) and his 9 siblings, 5 of whom were carriers of chronic pancreatic hyperenzymemia. $\mathrm{nv}=$ normal values

\begin{tabular}{|c|c|c|c|c|c|}
\hline 营 & 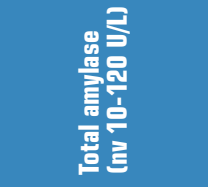 & 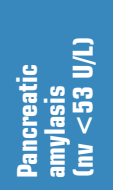 & 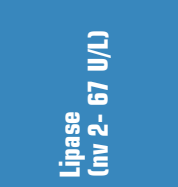 & 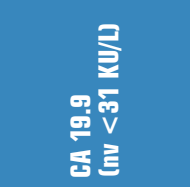 & 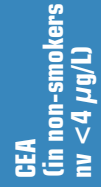 \\
\hline 2005 & 93 & & 150 & 8.04 & \\
\hline २००८, March & 115 & & 151 & 2.44 & \\
\hline 2008, December & 160 & & 387 & 2.04 & \\
\hline २००९, February & 181 & & 489 & & \\
\hline 2009, December & 66 & & 22 & 3.55 & \\
\hline 2010 & 90 & & 76 & & \\
\hline 2011, May & 134 & & 309 & & \\
\hline 2011, November & 228 & & 670 & 9.02 & \\
\hline 2012, February & 65 & & 32 & & \\
\hline 2012, June & 87 & & 59 & 7.89 & \\
\hline २012, September & 156 & & 411 & 8.07 & \\
\hline 2013, January & & 21 & 39 & 8.90 & \\
\hline 2016 & & 129 & 766 & & \\
\hline 2017 & & 86 & 504 & & \\
\hline 2018 & & 22 & & & \\
\hline 2019, February & 151 & & 364 & & \\
\hline २019, September & 117 & 75.8 & 219 & 80 & 1.8 \\
\hline \multicolumn{6}{|c|}{ 2019, October: colon adenocarcinoma, right hemicolectomy } \\
\hline 2019, December & & & & 4.2 & 1.5 \\
\hline २०२०, February & & & & 10.8 & 3 \\
\hline २०२०, June & 65 & & 27 & $9.2(n v<35.4)^{*}$ & 3.3 \\
\hline 20२0, October & & & & 10.6 & 2 \\
\hline 20२0, November & 141 (nv: <100)* & & $402(\mathrm{nv}<60) *$ & & \\
\hline
\end{tabular}

Table II. Summary table of pancreatic enzyme (and oncologic markers) values in our patient relating to 19 consecutive blood tests, found over a 15-year period. Maximum values reached are in bold. Lipase and total amylase were measured with kinetic colorimetric method, pancreatic amylasis using enzymatic kinetic method, and CA 19.9 and CEA employing chemiluminescence.

$\mathrm{nv}=$ normal values *change in normal values in 202 
Figure 2. Graphic representation of maximum serum values of pancreatic enzymes (38 determinations) over 15 years in our patient. Enzymes were abnormally elevated, albeit with fluctuations and transient normalization. In the period 2013-2019 only pancreatic amylases were measured in our laboratory.

$\mathrm{nv}=$ normal values

Figure 3. Fluctuating values of total amylase and lipase from 2005 to November 2020. In the period 2013-2019 only pancreatic amylases were measured in our laboratory.

$\mathrm{nv}=$ normal values
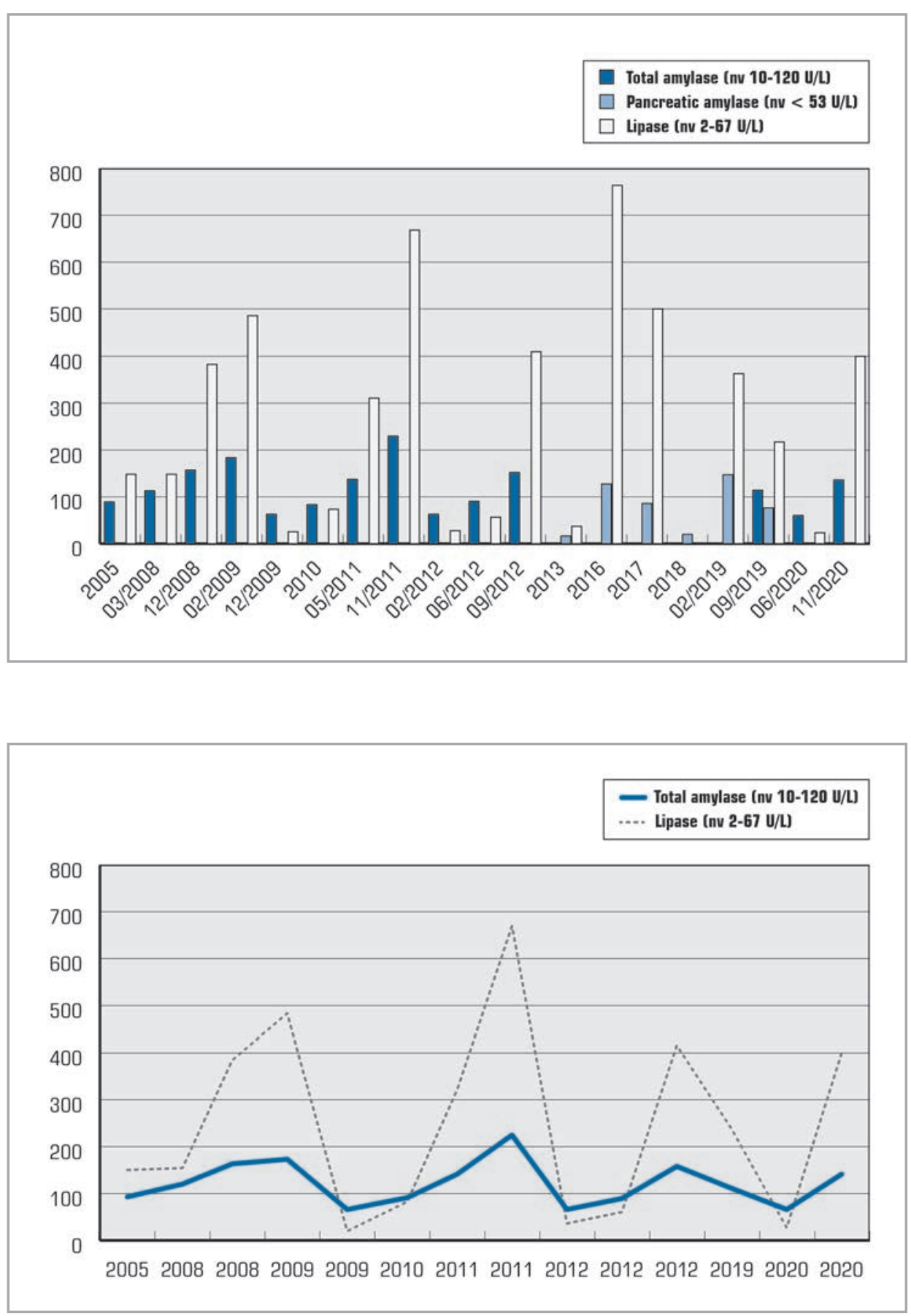

He did not use any drug that could induce hyperamylasemia or hyperlipasemia (Box 1 [6]) or acute pancreatitis (Box 2 [7]).

His family history revealed:

- a mother who died at the age of 63 years after cholecystectomy for multiple cholelithiasis;

- out of 10 siblings, half were carriers of hyperamylasemia (with a maximum value of $1900 \mathrm{U} / \mathrm{L}$ ) and/or hyperlipasemia (with a maximum value of $1622 \mathrm{U} / \mathrm{L}$ ), found after the age of 27-44 years;
- a sister, born in 1936, suffering from Hashimoto's thyroiditis and myelofibrosis, died at 82 years from aplastic anemia;

- a brother, born in 1945, is a carrier of prostate cancer and has pancreatic cysts on abdomen CT scan;

- a 69-year-old brother is a carrier of cystic pancreatic lesions detected by CT scan;

- a brother, born in 1956, is a carrier of isolated hyperenzymemia;

- it should also be noted that out of two sisters without hyperenzymemia, one died at 


\begin{tabular}{|c|c|c|c|c|c|c|c|c|c|c|c|c|c|}
\hline \multirow[t]{3}{*}{ Parameter } & \multicolumn{12}{|c|}{ Detected level } & \multirow[t]{3}{*}{$\begin{array}{c}\text { Normal } \\
\text { range }\end{array}$} \\
\hline & \multicolumn{2}{|c|}{2018} & \multicolumn{3}{|c|}{2019} & \multicolumn{7}{|c|}{2020} & \\
\hline & $\begin{array}{l}\text { 룰 } \\
\text { 톨 }\end{array}$ & 롤 & 롤 & 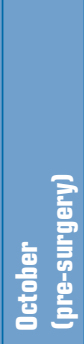 & 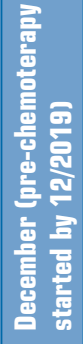 & $\begin{array}{l}\text { 롤 } \\
\text { 㡲 } \\
\text { 镸 }\end{array}$ & $\begin{array}{l}\text { 롤 } \\
\text { 롫 } \\
\text { 횬 }\end{array}$ & $\begin{array}{l}\text { 훌 } \\
\text { 롤 }\end{array}$ & 兽 & 클 & $\begin{array}{l}\text { 흄 } \\
\text { 횸 }\end{array}$ & 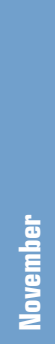 & \\
\hline Glucose $(\mathrm{mmol} / \mathrm{L})$ & 7.6 & & 5.2 & 7.5 & & & & & & 7.5 & 7.7 & & $3.35-5.55$ \\
\hline Glycated hemoglobin (\%) & & 6.2 & 5.8 & 4.7 & & & & & & & 6.3 & & $4-6$ \\
\hline Aspartate aminotransferase (U/L) & 17 & & & 23 & 19 & 18 & 20 & 17 & 37 & 26 & 29 & & $<35$ \\
\hline Alanine aminotransferase $(\mathrm{U} / \mathrm{L})$ & 14 & 23 & & 29 & 23 & 15 & 20 & 14 & 34 & 22 & 39 & & $<45$ \\
\hline Total bilirubin ( $\mu \mathrm{mol} / \mathrm{L})$ & & & & & 10.5 & 8.9 & 11.3 & 9.8 & 16.3 & 16.9 & 13 & & $1.7-17$ \\
\hline Conjugated bilirubin ( $\mu \mathrm{mol} / \mathrm{L})$ & & & & & 4.3 & 4.0 & 4.9 & 3.8 & 6.4 & 2.85 & & & $<5.1$ \\
\hline$\gamma$-glutamyltransferase & & & & 35 & 34 & & & & & 51 & 70 & 60 & $3-55$ \\
\hline Sodium (mmol/L) & & & & 139 & 138 & 138 & 142 & 140 & 138 & 146 & 136 & & $136-145$ \\
\hline Potassium (mmol/L) & & & & 3.8 & 3.8 & 3.9 & 3.8 & 3.8 & 3.8 & 4.7 & 3.8 & & \\
\hline Total creatine kinase (U/L) & 117 & & & & & & & & & & & & $<171$ \\
\hline C-reactive protein (mg/L) & 30.46 & & & & & & & & & 3.27 & & & $<5$ \\
\hline Creatinine $(\mu \mathrm{mol} / \mathrm{L})$ & & 83 & 87 & 99 & 103 & 103 & 95 & 102 & 116 & 104 & 93 & & $64-104$ \\
\hline Total cholesterol (mmol/L) & & & 5.11 & 5.05 & & & & & & 4.9 & & & $<4.92$ \\
\hline HDL cholesterol (mmol/L) & & & 1.21 & 1.18 & & & & & & 1.06 & & & $<1.40$ \\
\hline Triglycerides (mmol/L) & & & 1.10 & 1.61 & & & & & & 1.36 & & & $<1.70$ \\
\hline Prostate specific antigen (PSA) ( $\mu \mathrm{g} / \mathrm{L})$ & & 1.69 & & 1.73 & 1.42 & & & & & 1.23 & 1.51 & & $<4$ \\
\hline Red blood cells ( $\left.\times 10^{12} / L\right)$ & & 5.39 & & 5.24 & 4.86 & 4.9 & 4.42 & 4.37 & 4.05 & 4.55 & 5.53 & & $4.50-5.50$ \\
\hline Hemoglobin $(\mathrm{g} / \mathrm{L})$ & & 161 & & 155 & 142 & 141 & 128 & 136 & 136 & 147 & 163 & & $135-160$ \\
\hline Platelets $\left(\times 10^{9} / \mathrm{L}\right)$ & & 165 & & 144 & 161 & 160 & 142 & 180 & 130 & 170 & 156 & & $150-400$ \\
\hline White blood cells $\left(\times 10^{9} / \mathrm{L}\right)$ & & 7.19 & & 1.88 & 5.85 & 4.15 & 3.6 & 4.46 & 3.02 & 4.34 & 4.80 & & $4-10$ \\
\hline Neutrophils $\left(\times 10^{9} / \mathrm{L}\right)$ & & 4.23 & & 1.31 & 3.42 & 1.92 & 1.97 & 2.36 & 1.39 & 2.45 & 2.32 & & $1.9-8$ \\
\hline Total protein $(\mathrm{g} / \mathrm{dL})$ & & & 6.8 & 6.7 & & & & & & 6.9 & & & $6.6-8.7$ \\
\hline Albumin (\%) & & & 66.4 & 66.1 & & & & & & & & & $55.8-66.1$ \\
\hline$\alpha$-1-globulins (\%) & & & 2.8 & 3.1 & & & & & & & & & $2.9-4.9$ \\
\hline$\alpha$-2-globulins (\%) & & & 8.1 & 7.8 & & & & & & & & & 7.1-11.8 \\
\hline B-1-globulins (\%) & & & 6.3 & 6.3 & & & & & & & & & $4.7-7.2$ \\
\hline B-2-globulins (\%) & & & 4.3 & 4.5 & & & & & & & & & $3.2-6.5$ \\
\hline$\gamma$-globulins (\%) & & & 12.1 & 11.8 & & & & & & & & & $11.1-18.8$ \\
\hline
\end{tabular}

79 years for cancer of the breast and pancreas, while the other, 81-year-old, carries multiple cysts of pancreas, kidney, and liver.

The genealogic tree is shown in Figure 1, whilst Table I details the clinical features of the family members.

In our subject the presence of macroamylasemia and macrolipasemia was excluded (as well as macro-creatine phosphokinase-
macro-CPK). The periodic control of oncological markers (CA19-9) was negative.

The evolution over time of total amylase, pancreatic amylase, and lipase values is shown in Table II and Figures 2 and 3. Additional laboratory tests are shown in Table III.

In 2018, after 38 years from the first finding of hyperenzymemia, the magnetic resonance imaging (MRI) findings of the upper abdo-
Table III. Summary table of laboratory tests performed during the last two years $(2018$ 2020), before and after surgery (hemicolectomy) with subsequent chemotherapy. 
Figure 4. Findings from magnetic resonance cholangiopancreatography (MRCP) performed in 2018. The arrows indicate normal pancreas ( $A$ and $B)$.
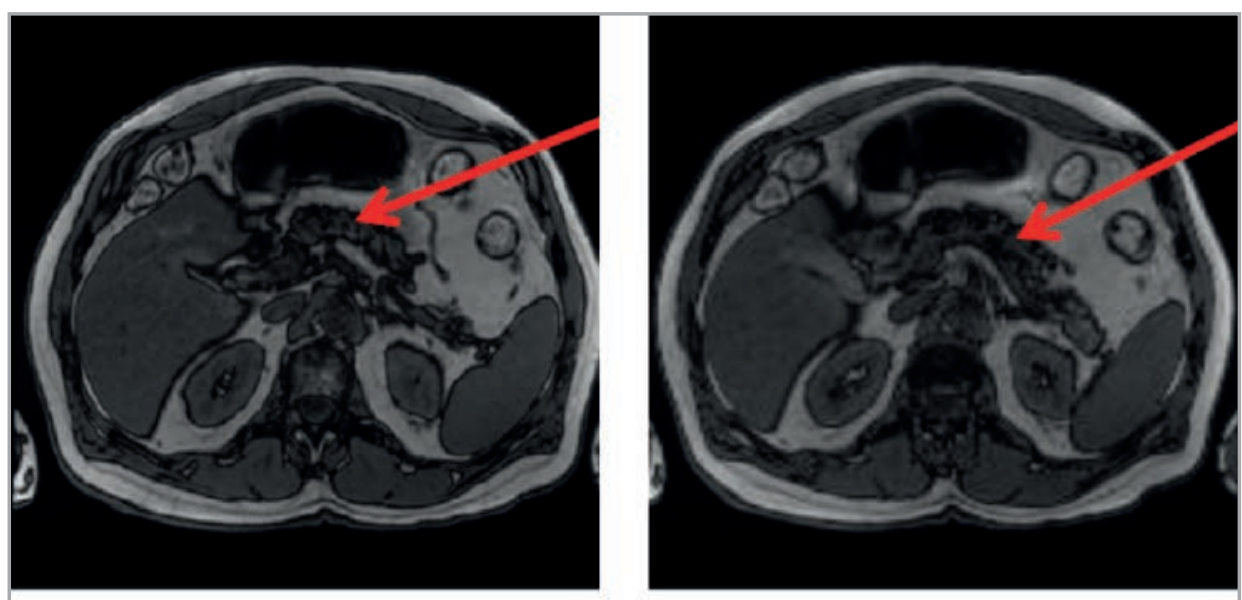

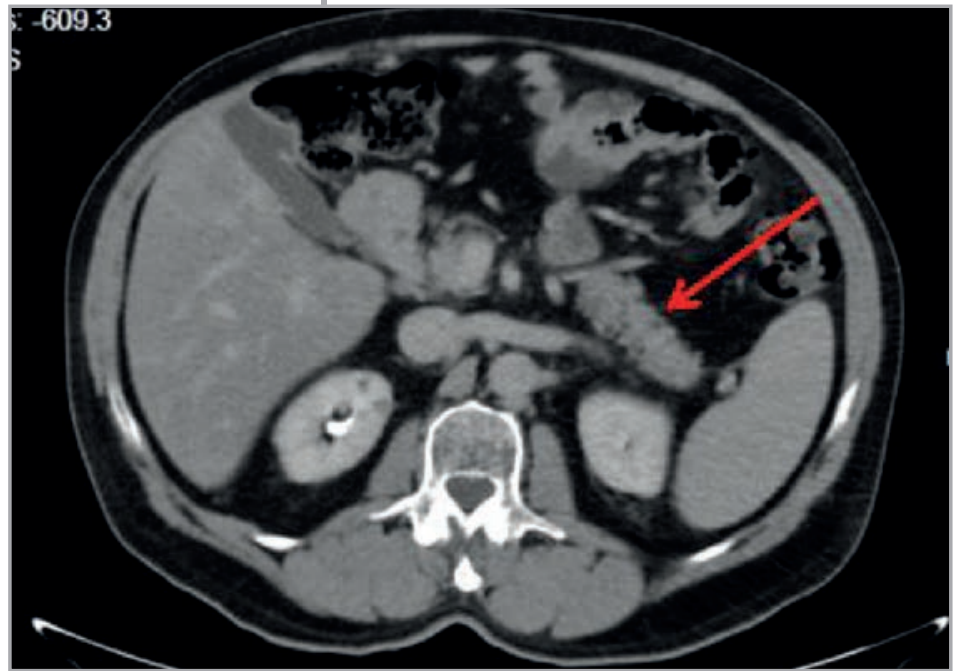

Figure 5. Contrastenhanced abdominal CT scan in October 2020 showed normal pancreas (red arrow). men revealed: liver containing some small cystic formations scattered in both lobes, the greatest being $10 \mathrm{~mm}$ large; pancreas within limits; some bilateral renal cystic cortical formation, greater than $17 \mathrm{~mm}$; no areas of pathological enhancement after paramagnetic contrast medium infusion (gadoteridol) of the upper abdomen organs. The magnetic res- onance cholangio-pancreatography (MRCP) [2] showed no biliary lithiasis, no dilatation of the intrahepatic biliary tree, hepato-choledochus with a maximum caliber of $7 \mathrm{~mm}$, regular Wirsung duct (Figure 4).

The laboratory tests performed in February 2019 (Table II) demonstrated: total amylase $=151 \mathrm{U} / \mathrm{L}(\mathrm{nv} 10-120 \mathrm{U} / \mathrm{L}), \mathrm{li}^{-}$ pase $=364 \mathrm{U} / \mathrm{L}(\mathrm{nv} 2-67 \mathrm{U} / \mathrm{L}), \gamma \mathrm{GT}=53$ $\mathrm{U} / \mathrm{L}(\mathrm{nv}<55 \mathrm{U} / \mathrm{L})$, blood glucose $=107 \mathrm{mg} /$ $\mathrm{dL}$, total cholesterol $=197 \mathrm{mg} / \mathrm{dL}$, triglicerides $=153 \mathrm{mg} / \mathrm{dl}$. The laboratory tests in September 2019 have found: lipase $=219$ U/L (nv 13-60 U/L), $\alpha$-amylase = 117 U/L (nv 28-100 U/L), pancreatic iso-amylase $=75.8 \mathrm{U} / \mathrm{L}(\mathrm{nv} 13-53 \mathrm{U} / \mathrm{L})$, faecal calprotectin $=81 \mu \mathrm{g} / \mathrm{g}$ faeces $(\mathrm{nv}<50 \mu \mathrm{g} / \mathrm{g})$ [8], CA 19-9 = $80 \mathrm{KU} / \mathrm{L}$ (nv <31 KU/L), positive occult blood in the faeces.

In October 2019, colonoscopy showed an ulcer in the right flessure and the biopsy revealed an adenocarcinoma. The patient underwent right hemicolectomy (October 2019) and subsequent 8 cycles of chemotherapy (oxaliplatin + capecitabine). He was negative for the nasopharyngeal swab

What should the clinician ask him/herself or the patient?

- Are changes in pancreatic enzymes associated with abdominal disorders?

- Was the finding of hyperamylasemia and/or hyperlipasemia occasional?

- Is periodic control of pancreatic enzymes recommended?

- What first level investigations should be performed?

- Which second level investigations are to be considered optional?

- How long should pancreatic enzymes be monitored?

- Is there familiarity?

- When can we reassure the patient about the benignity of the anomaly?

- Could there be dietary suggestions or drug treatments capable of reducing the pancreatic abnormality? 
for COVID-19. Laboratory tests in June 2020 , after the last course of chemotherapy, showed: amylase $=65 \mathrm{U} / \mathrm{L}($ nv 10$120 \mathrm{U} / \mathrm{L})$, lipase = $27 \mathrm{U} / \mathrm{L}(\mathrm{nv} 2-67 \mathrm{U} / \mathrm{L})$, CA $19-9=9.2 \mathrm{KU} / \mathrm{L}(\mathrm{nv}<35.4 \mathrm{KU} / \mathrm{L})$, $\mathrm{CEA}=3.3 \mu \mathrm{g} / \mathrm{L}(\mathrm{nv}<4.0 \mu \mathrm{g} / \mathrm{L})$. The contrast-enhanced abdominal CT scan revealed normal pancreas, minute hypodensity of cystic appearance in the liver, bilateral renal cysts, the largest $24 \mathrm{~mm}$ on the left.

The most recent laboratory tests, performed in November 2020 (Tables II), detected serum amylase $=141 \mathrm{U} / \mathrm{L}(\mathrm{nv}<100$ $\mathrm{U} / \mathrm{L})$ and serum lipase $=402 \mathrm{U} / \mathrm{L}(\mathrm{nv}<60$ U/L). The contrast-enhanced abdominal CT showed normal pancreas, unchanged liver, and kidney cysts (Figure 5).

\section{DISCUSSION}

Our clinical case meets the criteria for the definition of chronic asymptomatic pancreatic hyperenzymemia. In fact, the diagnostic criteria are $[9,10]$ :

- an increase by $>10 \%$ of the upper normal limits of serum amylase and/or lipase found on $>3$ occasions, lasting more than 6 months;

- absence of upper abdominal or back pain;

- idiopathic presentation.

We excluded through the MRCP the presence of any associated congenital anomalies (pancreas divisum, annular pancreas, Wirsungocele, cystic lesions at the pancreatic tail, Santorinicele, diffuse dilation of the main pancreatic duct) and intraductal papillary mucinous tumor of the pancreas, as these alterations have been described in some cases [11-14]. We did not perform a MRCP with secretin stimulation, currently considered as the method of choice in the study of CAPH subjects $[9,15]$ for the search for sphincter of Oddi dysfunction or even early (mild) chronic pancreatitis: this investigation would not have added significant data to the always stable clinical picture. Similar considerations apply to the use of endoscopic ultrasonography [16-18].

In the family group in analysis, two brothers with hyperenzymemia had pancreatic cysts, while a third brother had only hepatic and renal cysts. Of two siblings without hyperenzymemia, one had multiple cysts in the pancreas, kidney, and liver, while the second died due to pancreas (and breast) cancer at the age of 79 years. The significance of these associations, as well as the appearance of colon adenocarcinoma in our patient, at the present time is not clear.

The patients must be followed for a period of at least one year before labeling their pancreatic hyperenzymemia as benign, because in 1-2\% of cases of pancreatic cancer, asymptomatic pancreatic hyperenzymemia can be an early witnessed laboratory abnormality, especially in elderly age group $[19,20]$.

In adulthood, the prevalence of incidentally found pancreatic cystic lesions is high (between 2.6\% and 19.6\%) [21-24]. They are heterogeneous and include malignant, benign, and pre-malignant lesions, capable of evolving into invasive carcinoma over time. The differential diagnosis between intraductal papillary mucinous neoplasm, mucinous cystoadenoma and serous cystoadenoma could be made by endoscopic ultrasonography fine needle aspiration or even better with endoscopic ultrasonography through-theneedle microforceps biopsy [25], with the determination of intracystic glucose concentration, having been found to be more sensitive than the concentration of carcinoembryonic antigen [24]; however, this investigation is not carried out in our hospital.

It should be considered that a long-lasting CAPH, defined as benign, should be studied in depth at least with MRCP for the possibility, among others, of finding intraductal papillary mucinous neoplasm in small pancreatic cystic formations [12,14,26].

Also for this reason, the follow-up of hyperenzymemia must be continued for at least two years [27].

In our patient, after the end of chemotherapy for the colon adenocarcinoma, the fluctuations of lipase and amylase remained unchanged.

The ethiology of Gullo's syndrome remains unknown. It is known that there is a defect in the basolateral surface of the acinar cells that causes the increased secretion of pancreatic enzymes into the blood or the effect of secretin in the pancreatic duct of Wirsung [2].

Regarding the study of cystic fibrosis transmembrane conductance regulator (CFTR) gene mutations and serine peptidase inhibitor, Kazal type 1 (SPINK1) and serine protease 1 (PSSR1) genes, no significant differences compared to the general population have been described in benign familial hyperenzymemia [28-30].

The prevalence of CAPH among subjects who underwent blood tests for multiple pancreatic serum enzymes was $2 \%$ in 
a retrospective cross-sectional observational study in a large sample of the general Italian population [31].

In another Italian case series relating to 125,483 total accesses registered in a University Emergency Department [32], a prevalence of benign pancreatic hyperenzymemia equal to $0.09 \%$ cases for every 100,000 accesses was found.

Unlike the very extensive Italian cases, reports in other countries are limited. In literature, few cases are reported in Japan $[4,11]$, Belgium [14], USA [17,33], India [34], Taiwan [35], Brazil [36], Austria [37], Poland [38], Ukraine [39], Australia [40], Spain [41,42], Venezuela [43], Morocco [44], and Germany [45].

The most recent Italian case series was published in December 2019 [46].

Pancreatic hyperenzymemia can appear at almost every age: the ratio of affected men and women is $1.5: 1$. It is a rare finding in children: only a few sporadic cases have been described in the literature [41,47-49].
The coexistence of hyperenzymemia in siblings is diagnostic for familial form of $\mathrm{CAPH}$, which has an incidence between $4 \%$ and $39 \%$ in the series described in the literature $[3,8,10,12,39,43,50]$.

\section{CONCLUSION}

In the family group here described, the long follow-up between 31 and 40 years confirms the benignity of the enzymatic anomaly regarding pancreatic diseases. This familial association supports the concept of a genetic basis underlying pancreatic enzyme abnormalities, despite the fact that so far no correlations have been found with the genetic mutations studied.

\section{CONSENT TO PUBLICATION}

The consent to publication was obtained from the patient here described.

\section{Keypoints}

- The increase in serum amylase and/or lipase affects the extension of first-level laboratory and instrumental investigations aimed at confirming the presence of a pancreatic pathology.

- Pancreatic hyperenzymemia may be secondary to extra-pancreatic diseases.

- The periodic, but persistent over time, fluctuations of these enzymes with frequent return to normalization can result in chronic pancreatic hyperenzymemia (Gullo's Syndrome), which is considered in most cases to be a benign enzymatic anomaly.

- Gullo's Syndrome remains a diagnosis by exclusion: from the first finding of byperenzymemia it is necessary to wait two years before confirming it.

- In order to reach the diagnosis of CAPH, "second level" radiological investigations (MRCP, endoscopic ultrasonography) are necessary to rule out pancreatic anomalies (especially) of an anatomical type.

- The presence of this anomaly in relatives is an indicative element to confirm the diagnosis and its benignity.

\section{Funding}

This article has been published without the support of sponsors.

\section{Conflicts of interests}

The authors declare they have no competing financial interests concerning the topics of this article.

\section{ORCID}

Mauro Turrin: https://orcid.org/0000-0003-2100-2104

Lucia Fornasiero: https://orcid.org/0000-0003-1138-8613

\section{REFERENCES}

1. Gullo L, Lucrezio L, Migliori M, et al. Benign pancreatic hyperenzymemia or Gullo's syndrome. Adv Med Sci 2008; 53: 1-5; https://doi.org/10.2478/v10039-008-0027-7

2. Gullo L, Lucrezio L, Calculli L, et al. Magnetic resonance cholangiopancreatography in asymptomatic pancreatic hyperenzymemia. Pancreas 2009; 38:396-400; https://doi.org/10.1097/ MPA.0b013e31819d73b3 
3. Galassi E, Birtolo C,Migliori M, et al. A 5-year experience of benign pancreatic hyperenzymemia. Pancreas 2014; 43: 874-8; https:/doi.org/10.1097/MPA.0000000000000138

4. Masuko K, Morishita T. Chronic Asymptomatic Hyperenzymemia of the Pancreas Suggestive of the Presence of Undiagnosed Sjögren Syndrome. Pancreas 2020; 49: e85-e86; https://doi. org/10.1097/MPA.0000000000001645

5. Iida T, Wagatsuma K, Hirayama D, et al. The Etiology of Pancreatic Manifestations in Patients with Inflammatory Bowel Disease.J Clin Med 2019; 8: 916; https://doi.org/10.3390/jcm8070916

6. Frulloni L, Patrizi F, Bernardoni L, et al. Pancreatic hyperenzymemia: clinical significance and diagnostic approach. JOP 2005; 6: 536-51

7. Turrin M. Rare Causes of Acute Pancreatitis: Drugs, Eosinophilia, and Autoimmunity. OBM Hepatology and Gastroenterology 2019; 3: 20; https://doi.org/10.21926/obm.hg.1903034

8. Pezzilli R. Familial pancreatic hyperenzymemia. Pancreatic Dis Ther 2013; S1: e001; https:// doi.org/10.417272165-7092.s1-e001

9. Di Leo M, Petrone MC, Zuppardo RA, et al. Pancreatic morpho-functional imaging as diagnostic approach for chronic asymptomatic pancreatic hyperenzymemia. Dig Liver Dis 2016; 48: 1330-5; https://doi.org/10.1016/j.dld.2016.08.109

10. Amodio A, Manfredi R, Katsotourchi AM, et al. Prospective evaluation of subjects with chronic asymptomatic pancreatic hyperenzymemia.Am J Gastroenterol 2012; 107: 1089-95; https://doi. org/10.1038/ajg.2012.125

11. Gonoi W, Hayashi TY, Hayashi N, et al. Association between chronic asymptomatic pancreatic hyperenzymemia and pancreatic ductal anomalies: a magnetic resonance cholangiopancreato graphy study. Abdom Radiol (NY) 2019; 44: 2494-500; https://doi.org/10.1007/s00261-019-02004-4

12. Pezzilli R,Morselli-Labate AM,Casadei R,et al.Chronic asymptomatic pancreatic hyperenzymemia is a benign condition in only half of the cases: a prospective study. Scand J Gastroenterol 2009; 44: 888-93; https://doi.org/10.1080/00365520902839683

13. Testoni PA, Mariani A, Curioni S, et al. Pancreatic ductal abnormalities documented by secretinenhanced MRCP in asymptomatic subjects with chronic pancreatic hyperenzymemia. Am J Gastroenterol 2009; 104: 1780-6; https://doi.org/10.1038/ajg.2009.158

14. Mortelè KJ, Wiesner W, Zou H, et al. Asymptomatic nonspecific serum hyperamylasemia and hyperlipasemia: spectrum of MRCP findings and clinical implications. Abdomen Imaging 2004; 29: 109-14; https://doi.org/10.1007/s00261-003-0072-4

15. Amodio A,De Marchi G, Granato A, et al. Chronic asymptomatic pancreatic hyperenzymemia: a long-term follow-up. Pancreas 2019; 48:544-7; https://doi.org/10.1097/MPA.0000000000001272

16. Antonini F, Belfiori V, Pagano N, et al. Endoscopic ultrasonography may select subjects who require a stricter follow-up. Pancreas 2017; 46: 524-7; https://doi.org/10.1097/ MPA.0000000000000796

17. Sitaraman LM, Sachdev AH, Gonda TA, et al. The utility of endoscopic ultrasound in patients with isolated elevations in serum amylase and/or lipase. Clin Endosc 2019; 52: 175-81; https:// doi.org/10.5946/ce.2018.110

18. Vanella G, Arcidiacono PG, Capurso G. Chronic asymptomatic pancreatic hyperenzymemia (CAPH): meta-analysis of pancreatic finding at second-level imaging. Pancreatology 2019; 19: 237-44; https://doi.org/10.1016/ j.pan.2019.01.022

19. Gullo L. Benign pancreatic hyperenzymemia. Dig Liver Dis 2007; 39: 698-702; https://doi. org/10.1016/j.dld.2007.03.005

20. Catanzaro R, Italia A. Iperenzimemia pancreatica: recenti acquisizioni in tema di approccio clinico-diagnostico, con particolare attenzione alla sindrome di Gullo [Pancreatic hyperenzymemia: new advances in the field of clinical-diagnostic approach, with particular attention about Gullo's syndrome]. Minerva Med 2012; 103: 393-412

21. Zerboni G, Signoretti M, Crippa S, et al. Systematic review and meta-analysis: Prevalence of incidentally detected pancreatic cystic lesions in asymptomatic individuals. Pancreatology 2019; 19: 2-9; https://doi.org/10.1016/j.pan.2018.11.014. Epub 2018 Nov 28

22. Zhu S, Wang WT, Shang XS, et al. Difference analysis in prevalence of incidental pancreatic cystic lesions between computed tomography and magnetic resonance imaging. BMC Med Imaging 2019; 19: 43; https://doi.org/10.1186/s12880-019-0341-5

23. Khoury T, Kadah A, Mari A, et al. The utility of endoscopic ultrasound fine needle aspiration in pancreatic cystic lesions diagnosis. Diagnostics 2020; 10: 507; https://doi.org/10.3390/ diagnostics10080507

24. Ribaldone DG, Bruno M, Gaia S, et al. Differential diagnosis of pancreatic cysts: A prospective study on the role of intra-cystic glucose concentration. Dig Liver Dis 2020; 52: 1026-32; https:// doi.org/10.1016/j.dld.2020.06.038. Epub 2020 Jul 13

25. Tacelli M, Celsa C, Magro B, et al. Diagnostic performance of endoscopic ultrasound throughthe-needle microforceps biopsy of pancreatic cystic lesions: Systematic review with meta-analysis. Dig Endosc 2020; 32: 1018-30; https://doi.org/10.1111/den.13626 
26. Pezzilli R,Morselli-Labate AM, Calculli L, et al. Long-Standing Pancreatic Hyperenzymemia: Is It a Nonpathological Condition? Case Rep Gastroenterol 2009; 3: 111-5; https://doi. org/10.1159/000213479

27. Birtolo C, Migliori M, Drewes AM, et al. Benign pancreatic hyperenzymemia: lights on a clinical challenge. Pancreas 2017; 46: 5-7; doi: 10.1097/MPA.0000000000000723

28. Gullo L, Mantovani V, Manca M, et al. Mutations of the CFTR gene in idiopathic pancreatic hyperenzymemia. Pancreas 2005; 31: 350-2

29. Gullo L, Laghi L, Migliori M, et al. SPINK1 and PRSS1 mutations in benign pancreatic hyperenzymemia. Pancreas 2008; 37: 31-5; https://doi.org/10.1097/MPA.0b013e31816172b7

30. Valente R, Antonelli M, Piciucchi M, et al. Celiac disease and CFTR mutations in patients with chronic asymptomatic pancreatic hyperenzymemia. Am J Gastroenterol 2013; 108: 618; https://doi.org/10.1038/ajg.2013.13

31. Cavallo P, Carpinelli L, Zingone F, et al. Prevalence and correlates of benign pancreatic hyperenzymemia in a large general population sample: the Damocles sword perception. Pancreatology 2019; 19: 409-13; https://doi.org/10.1016/j.pan.2019.03.003

32. Murabito LM, Famà F, Gioffrè-Florio MA. Benign pancreatic hyperenzimemia or Gullo's syndrome: incidence in patients admitted to an emergency department. Gazzetta Medica Italiana Archivio per le Scienze Mediche 2016; 175: 40-7

33. Mehta P, Reddivari AKR. A Case Report of Benign Pancreatic Hyperenzymemia (Gullo's Syndrome). Cureus 2020; 12: e8143; https://doi.org/10.7759/cureus.8143

34. Kumar P, Ghosh A, Tandon V, et al. Gullo's Syndrome: A Case Report. J Clin Diagn Res 2016; 10: OD21-OD22; https://doi.org/10.7860/JCDR/2016/17038.7285. Epub 2016 Feb 1

35. Yang BL, Wu WC, Su CW, et al. Healthy Chinese with benign pancreatic hyperenzymemia.J Chin Med Assoc 2015; 78: 623-6; https://doi.org/10.1016/j.jcma.2015.05.011.Epub 2015 Aug 10

36. Wiederkehr JC, Wiederkehr BA, Wiederkehr HA, et al. Nonspecific hyperamylasemia: a case report.JOP 2013; 14: 74-6; https://doi.org/10.6092/1590-8577/1216

37. Schnedl WJ, Enko D, Mangge H, et al. Benign pancreatic hyperenzymemia (Gullo syndrome), histamine intolerance, and carbohydrate malabsorption. Proc (Bayl Univ Med Cent) 2017; 30: 177-8; https://doi.org/10.1080/08998280.2017.11929574

38. Rycyk A, Furtak P, Mądro A, et al. Gullo's Syndrome: case report. J Pre-Clin Clin Res 2020; 14: 117-9; https://doi.org/10.26444/jpccr/127792

39. Gubergrits NB, Gubska O, Klochkov AY, et al. Clinical Case Report of Familial Benign Pancreatic Hyperenzymemia. Pancreas 2018; 47: e35-e36; https://doi.org/10.1097/ MPA.0000000000001078

40. Bachmeier CAE, Morton A. Man with epigastric pain and persistently elevated serum lipase. BMJ Case Reports CP 2019; 12: e229208

41. Rosell-Camps A, Martínez-Cepas P, Riera-Llodrá JM, et al. Benign Pancreatic Hyperenzymemia, Also Known as Gulloss Syndrome. Lab Med 2020; 51:423-5; https://doi.org/10.1093/labmed/lmz077

42. de Alba Iriarte B, López N, Rubio A, et al. Gullo’s Syndrome (Benign Pancreatic Hyperenzymemia): Report of the First Two Cases in Basque Country.J Case Rep Stud 2019; 7: 40

43. Pérez M, Colina N, Daoud G, et al. Hiperenzimemia pancreática benigna familiar: Sindrome de Gullo. A proposito de un caso [Familial benign pancreatic hyperenzimemia: a case report] Revista Gen 2016; 70: 23-7

44. Ainahi A, Ziane A, Wakrim L, et al. An Unusual Case of Gullo's Syndrome Concomitant with Serious Endometriosis Disease in a Postmenopausal Woman. Case Rep Med 2018; 2018 : 6310245; https://doi.org/10.1155/2018/6310245

45. Lankisch PG. Erhöhte Pankreasenzyme ohne erkennbare Pankreaserkrankung [Elevated pancreatic enzymes without evident pancreatic disease]. Dtsch Med Wochenschr 2009; 134: 22325; https://doi.org/ 10.1055/s-0029-1241932

46. Catanzaro R, Sciuto M, Adamo G, et al. Benign pancreatic hyperenzymemia-Gullo's syndrome: focus on this clinical challenge. A monocentric retrospective study. Minerva Med 2019; 110: 490-8; https://doi.org/10.23736/S0026-4806.19.06046-4

47. Gullo L, Migliori M. Benign pancreatic hyperenzymemia in children. Eur J Pediatr 2007; 166: 125-9; https://doi.org/10.1007/s00431-006-0264-3

48. Lionetti E, Francavilla R, Leonardi S, et al. Two rare cases of benign hyperlipasemia in children. World J Clin Cases 2014; 2: 16-9; https://doi.org/10.12998/wjcc.v2.i1.16

49. Parisi E, Carboni E, Mazza GD, et al. Benign pancreatic hyperenzymemia: Gullo's syndrome. Dig Liver Dis 2017; 49: e252; https://doi.org/101016/j.dld.2017.09.028;

50. Gullo L. Familial pancreatic hyperenzymemia. Pancreas 2000; 20: 158-60; https://doi. org/10.1097/00006676-200003000-00008 